Schulich School of Law, Dalhousie University

Schulich Law Scholars

Research Papers, Working Papers, Conference

Papers

Faculty Scholarship

7-3-2014

\title{
Fake It Till You Make it: Policymaking and Assisted Human Reproduction in Canada
}

Jocelyn Downie

Dalhousie University - Schulich School of Law, jocelyn.downie@dal.ca

Francoise Baylis

Dalhousie University, francoise.baylis@dal.ca

Dave Snow

Dalhousie University, dave.snow@dal.ca

Follow this and additional works at: https://digitalcommons.schulichlaw.dal.ca/working_papers

\section{Recommended Citation}

Downie, Jocelyn; Baylis, Francoise; and Snow, Dave, "Fake It Till You Make it: Policymaking and Assisted Human Reproduction in Canada" (2014). Research Papers, Working Papers, Conference Papers. 16. https://digitalcommons.schulichlaw.dal.ca/working_papers/16

This Working Paper is brought to you for free and open access by the Faculty Scholarship at Schulich Law Scholars. It has been accepted for inclusion in Research Papers, Working Papers, Conference Papers by an authorized administrator of Schulich Law Scholars. For more information, please contact hannah.steeves@dal.ca. 


\title{
Fake it Till You Make it: Policymaking and Assisted Human Reproduction in Canada
}

\author{
Françoise Baylis, PhD, ${ }^{1}$ Jocelyn Downie, MLitt, SJD, ${ }^{1,2,3}$ Dave Snow, PhD ${ }^{1}$ \\ ${ }^{1}$ Novel Tech Ethics, Faculty of Medicine, Dalhousie University, Halifax NS \\ ${ }^{2}$ Faculty of Law, Dalhousie University, Halifax NS \\ ${ }^{3}$ Faculty of Medicine, Dalhousie University, Halifax NS
}

\begin{abstract}
The Assisted Human Reproduction Act (AHR Act) came into effect in 2004. The AHR Act stipulates in s.12 that no reimbursement of expenditures incurred in the course of donating gametes, maintaining or transporting in vitro embryos, or providing surrogacy services is permitted, except in accordance with the regulations and with receipts. Ten years later, Health Canada still has not drafted the regulations governing reimbursement. Section 12 is therefore still not in force. Health Canada and others have asserted that there is a Health Canada policy on reimbursement and that reimbursement with receipts is legally permissible. We dispute the existence of such a policy and its legitimacy (if it exists). We also challenge the decision by Health Canada not to produce regulations and thereby make it possible for Parliament to bring s.12 into force. This intentional lack of action is worrisome on at least two fronts. First, it sidesteps the processes required for regulations and thereby ducks the Parliamentary oversight very deliberately built into the AHR Act. Second, it leaves Canadians who provide and who access assisted human reproduction uncertain about what is and is not permitted, and therefore fearful of, or at risk of, prosecution. We conclude that Health Canada should take the steps necessary to put regulations in front of Parliament so that Parliament will then be able to pass regulations and bring s.12 into force. Canadians should demand no less.
\end{abstract}

\section{Résumé}

La Loi sur la procréation assistée (LPA) est entrée en vigueur en 2004. L'article 12 de la LPA stipule qu'il est interdit de rembourser les frais supportés par un donneur pour le don d'un ovule ou d'un spermatozoïde, par quiconque pour l'entretien ou le transport d'un embryon in vitro ou par une mère porteuse pour agir à ce titre, sauf en conformité avec les règlements (avec reçus). Dix ans plus tard, Santé Canada n'a toujours pas formulé de règlements régissant le

Key Words: Egg donation, assisted human reproduction, Assisted Human Reproduction Act, AHR Act, law, policy

Competing Interests: None declared.

Received on March 10, 2014

Accepted on March 26, 2014 remboursement. L'article 12 n'est donc toujours pas en vigueur. Santé Canada et d'autres intervenants ont soutenu qu'il existe une politique de Santé Canada sur le remboursement et que le remboursement sur présentation de reçus est permis au plan légal. Nous contestons l'existence d'une telle politique et sa légitimité (le cas échéant). Nous contestons également la décision de Santé Canada de ne pas formuler de règlements et d'empêcher ainsi l'entrée en vigueur de l'article 12. Cette inaction délibérée est troublante pour au moins deux raisons. Premièrement, elle contourne les processus requis pour ce qui est des règlements et se soustrait donc à la surveillance parlementaire qui a été intégrée à la LPA de façon très délibérée. Deuxièmement, elle expose les Canadiens qui offrent et qui utilisent des services de procréation assistée à de l'incertitude quant à ce qui est et à ce qui n'est pas permis, ce qui fait en sorte qu'ils ne savent donc pas s'ils s'exposent ou non à des poursuites. Nous en venons à la conclusion que Santé Canada devrait prendre les mesures nécessaires pour soumettre des règlements au Parlement, de façon à ce que ce dernier soit en mesure de les promulguer et d'assurer l'entrée en vigueur de l'article 12. Les Canadiens devraient l'exiger.

J Obstet Gynaecol Can 2014;36(6):510-512

The Assisted Human Reproduction Act (AHR Act) 1 includes a number of guiding principles. Among them is a statement declaring that "trade in the reproductive capabilities of women and men and the exploitation of children, women and men for commercial ends raise health and ethical concerns that justify their prohibition." Consistent with this declared principle, ss. 6 and 7 of the AHR Act respectively prohibit paying a woman to be a surrogate mother (i.e., to provide gestational services), accepting payment for arranging or offering to arrange a surrogacy agreement, and purchasing sperm or eggs from a donor or someone acting on behalf of a donor:

6. (1) No person shall pay consideration to a female person to be a surrogate mother, offer to pay such consideration or advertise that it will be paid. 
6. (2) No person shall accept consideration for arranging for the services of a surrogate mother, offer to make such an arrangement for consideration or advertise the arranging of such services.

7. (1) No person shall purchase, offer to purchase or advertise for the purchase of sperm or ova from a donor or a person acting on behalf of a donor.

Section 12 of the AHR Act further stipulates that no reimbursement of expenditures is permitted, except in accordance with the regulations and with receipts:

12. (1) No persons shall, except in accordance with the regulations,

(a) reimburse a donor for an expenditure incurred in the course of donating sperm or an ovum;

(b) reimburse any person for an expenditure incurred in the maintenance or transport of an in vitro embryo; or

(c) reimburse a surrogate mother for an expenditure incurred by her in relation to her surrogacy.

(2) No person shall reimburse an expenditure referred to in subsection (1) unless a receipt is provided to that person for the expenditure.

While ss.6 and 7 are in force, s.12 is not yet in force. Moreover, Health Canada has not created the regulations required before s.12 can be brought into force. As a result, there is considerable confusion about when, how much, and for what, a surrogate mother or an egg donor can be legally reimbursed with or without receipts.

In December 2013, this longstanding confusion was made worse. Leia Picard (sole director of Canadian Fertility Consulting Ltd.) admitted to violating ss. 6 and 7 of the AHR Act and received a fine of $\$ 60000$. Specifically, Ms Picard admitted to paying consideration between $\$ 22000$ and $\$ 26500$ to each of three female persons to be a surrogate mother (a violation of s.6(1)), and admitted to accepting consideration in the amount of $\$ 31000$ for arranging for the services of a surrogate mother (a violation of s.6(2)). She also admitted to the purchase of eggs from five women for 12 "donor" cycles at $\$ 5000$ per cycle (a violation of s.7(1)). ${ }^{2}$

Surprisingly, the "Agreed Statement of Facts" in the case included the following statement: "Health Canada policy permits reimbursement to donors and surrogates of expenses and disbursements related to donation or surrogacy." The problem with this statement is that it suggests that (a) there is a Health Canada policy, and (b) such a policy makes reimbursement with receipts legally permissible. This statement is problematic for at least three reasons.

First, evidence of the existence of a Health Canada policy on point remains elusive. One of the authors (J.D.) asked the Crown Prosecutor in the Picard case for a copy of the policy referred to in the Agreed Statement of Facts. The request was refused:

I can only provide material filed in court that has become a matter of public record. ... The release of anything related to Health Canada policy is purely a matter for the responsible department and must be pursued with Health Canada.

(personal communication with Thomas Lemon [General Counsel], January 23 and 27, 2014).

This response is troubling because any Health Canada policy should be public, and because the Crown submitted to the court the existence of a government policy as a matter of fact. Such a policy cannot be considered a confidential or privileged document. Moreover, it is surely not for the Crown and Defence counsel to agree between themselves, as a matter of fact, that there is a Health Canada policy in the absence of evidence that there actually is such a policy. In addition, two of the authors (J.D. and F.B.) requested of Health Canada a copy of any government policy related to s.12 of the AHR Act. Health Canada's only response was to point us to text on their website. Such text obviously fails any definition of a government policy.,

Second, it is not at all clear that Health Canada's interpretation of the law (implied in the Agreed Statement of Facts and conveyed directly in personal correspondence to Françoise Baylis and Jocelyn Downie from Lynn Mainland of Health Canada, September 24, 2013, and from Assisted Human Reproduction, Biologics and Genetic Therapies Directorate, December 16, 2014) is correct. Based on our interpretation of the 2010 Supreme Court of Canada's decision in "Reference re Assisted Human Reproduction Act," we have argued elsewhere ${ }^{6}$ that until regulations are passed and s.12 is brought into force, no reimbursements (with or without receipts) are permitted.

Third, the claim in the Agreed Statement of Facts lends authority to the claim made by others that there is a Health Canada policy on point and that reimbursement with receipts is permitted in Canada. In this way, with the Picard case, ${ }^{2}$ a second storey appears to have been added to the house built on sand by Health Canada.

The confusion here leaves Canadians who provide and who access assisted human reproduction uncertain about what is and is not permitted, and therefore fearful of, or at risk of, prosecution. This confusion could be readily 
resolved by Health Canada promulgating the regulations for s.12 and by Parliament bringing s.12 into force.

Health Canada's failure to promulgate regulations is deeply troubling, not only because it leaves providers and users of assisted human reproduction uncertain about what is permitted or prohibited, but also because it represents a failure to respect established law-making practices and requirements. Given the growing needs of the modern administrative state, regulation-delegated bureaucratic and administrative rule-making-has grown considerably over the last several decades. ${ }^{7}$ This is a good thing in that regulation offers opportunities for stakeholder consultation, flexibility, and freedom from political influence. However, if not properly scrutinized, the virtues of regulation can become its vices. Efficiency can quickly result in abuses of power if regulations are not made in accordance with formalized law-making procedures. ${ }^{8}$

Canada has several statutory safeguards designed to prevent such abuses. The Statutory Instruments Act (SI Act) and Statutory Instruments Regulation stipulate that regulations must undergo legal examination, registration, and formal publication. The regulatory process itself, as stipulated by the Privy Council Office, involves nine steps: proposal development, central agency review, pre-publication, approval, registration, coming into force, publication, distribution, and parliamentary scrutiny. Before publication, regulations must also undergo a Regulatory Impact Analysis Statement (RIAS), which outlines anticipated costs and benefits, public consultation efforts, compliance mechanisms, and performance measurement. The RIAS serves as a public document to ensure that the government is "accountable to Canadians and parliamentarians in the exercise of delegated authority for the making of laws." In addition, the Standing Joint Committee for the Scrutiny of Regulations, composed of Members of Parliament and Senators, has a statutory mandate to review all government regulations and, if necessary, propose to the House of Commons that the government disallow the regulation. ${ }^{10}$

Collectively, these safeguards ensure that democratic law-making procedures conform with the rule of law. Unfortunately, however, these formal processes have been sidestepped with respect to the AHR Act.

In addition to the above, the requirements for the introduction of regulations for the AHR Act are even stricter. The $A H R$ Actitself explicitly addresses the creation of regulations: s.65(e) empowers the government (through the Minister of Health) to create regulations "respecting the reimbursement of expenditures" for s.12(1) and "the reimbursement of a loss of income" for s.12(3). Section 66 states that the Minister of Health must lay new regulations before the House of Commons and the Senate, and these regulations "shall be referred to the appropriate committee of each House" (which for the House of Commons is the Standing Committee on Health). The only exceptions are at the extremes, as per s.67: either when regulatory changes are "so immaterial or insubstantial" that scrutiny is not required, or when a regulation "must be made immediately in order to protect the health or safety of any person."

Thus, according to decades-old parliamentary law, and now the AHR Act itself, regulations must be scrutinized, publicized, and evaluated to ensure transparency and accountability. Health Canada's position on reimbursements and receipts has obviously not been subject to parliamentary scrutiny, nor has it been reviewed by the Joint Committee for the Scrutiny of Regulations. It has not been publicized, unless one counts vague information posted on its website as publication. And finally, it has not been evaluated according to the RIAS. Health Canada has effectively, if not intentionally, ducked the oversight of this issue clearly intended by Parliament when the AHR Act was passed. This represents an avoidance of democratic accountability and compounds the vulnerability of Canadians who provide and who access assisted human reproduction. It should not be tolerated.

\section{REFERENCES}

1. Assisted Human Reproduction Act S.C. 2004, c. 2, s. 7.

2. R. v. Picard and Canadian Fertility Consulting Ltd. Agreed Statement of Facts. See paragraphs 5, 16-21, and 25-29. Available at: http://noveltechethics.ca/files/files/ELA2/AHR/AHRA_Facts.pdf. Accessed March 25, 2014.

3. Health Canada. Prohibitions related to purchasing reproductive material and purchasing or selling in vitro embryos. Ottawa: Health Canada. Available at: http://www.hc-sc.gc.ca/dhp-mps/brgtherap/legislation/ reprod/purchasing-achat-eng.php. Accessed March 25, 2014.

4. Health Canada. Prohibitions related to surrogacy. Ottawa: Health Canada. Available at: http://www.hc-sc.gc.ca/dhp-mps/brgtherap/legislation/ reprod/surrogacy-substitution-eng.php. Accessed March 25, 2014.

5. Reference re Assisted Human Reproduction Act, 2010 SCC 61, 3 SCR 457.

6. Downie J, Baylis F. Transnational trade in human eggs: law, policy, and (in) action in Canada. J Law Med Ethics 2013;41(1):224-39.

7. Levi-Faur D. Regulation and regulatory governance. In: Levi-Faur D. Handbook on the politics of regulation. Cheltenham: Edward Elgar; 2011:6.

8. Reid L. Oversight of regulation by parliamentarians. Canadian Parliamentary Review 2010;33(4):7.

9. Privy Council Office. Guide to making federal acts and regulations: part 3-making regulations. Ottawa: Privy Council Office; 2009. Available at: http://www.pco-bcp.gc.ca/index.asp?lang=eng\&page= information\&sub $=$ publications\&doc $=$ legislation $/$ part3-eng.htm. Accessed March 25, 2014.

10. Parliament of Canada. House of Commons procedure and practice, second edition, 2009: Standing joint committee for the scrutiny of regulations. Ottawa: Parliament of Canada; 2009. Available at: http://www.parl.gc.ca/procedure-book-livre/ Document.aspx?Language $=$ E\&sbdid $=519 \mathrm{e} 5 \mathrm{~b} 2 \mathrm{~b}-\mathrm{a} 6 \mathrm{ff}-49 \mathrm{e} 1$ b5c4-fe9ba384e253\&sbpid $=9$ eba9050-0b96-4602-b4ad336c59ba8bc6\&Mode=1. Accessed March 25, 2014. 